\title{
The Effect of Islamic Education Subject on the Development of Student Social Behavior
}

\author{
Diny Kristianty Wardany \\ Postgraduate Program in Islamic Education Management - Majalengka University, Indonesia \\ dinykw14@gmail.com
}

\begin{abstract}
This research departs from the assumption that learning Islamic Education is expected to be able to develop several obstacles in the lives of students both in the community and schools to students who behave well, learning activities and introduce good behavior to students, aiming to make students obedient in worshiping in the form of Islamic social morality. This research was conducted with quantitative methods, where data was taken through observation, interviews and research questionnaires, which were then processed using product moment techniques, the purpose of which was to find out the relationship between Islamic Education and the development of students' social behavior. The results showed that Islamic Education and students 'social behavior mostly showed good categories, and the results of hypothesis testing showed that learning Islamic Education had a strong relationship with the development of students' social behavior.
\end{abstract}

Keywords : Learning, Social Behavior, Islamic Education

\section{Introduction}

Education is a process in order to influence students to be able to complete themselves as best as possible with their environment, and thus will cause changes in the world that allow it to function in social life (Mulyanto 2007 : 52 ). Islamic religious education is a very urgent matter for children, as for the purpose of Islamic religious education is to guide children so that they become true Muslims, firm faith, pious charity and noble character and are useful to society, religion and the State. Based on Constitution of The Republic of Indonesia about education 2003 no. 20 (National Education System Law) affirms that religious education must be given to students, from the level of Kindergarten to university both for the level of education in Islamic and state school. In essence Islamic religious education has goals to be achieved, both general and specific in nature. (Supardi 2009:179) argued that the purpose of Islamic religious education is to instill piety and morals and uphold the truth to form human beings who are noble personalities according to Islamic teachings. (Arifin 2000:119) said that the purpose of Islamic education is to realize Islamic identity.

Research (Muhammad 2017) explains that religious education given to schools is an important factor as a basis for shaping the characteristics of students, so that they have a good attitude in accordance with Islamic norms. Therefore, religious education is included in character education, because it finds studies on how to be a good personality. The results of the study (Nakayama, Yamamoto, and Santiago 2007) in their study prove that character learning has more influence on learning performance in shaping students' character.

Through education, especially learning Islamic Education is expected to play a role as supporting the success of personality in students, especially social behavior. Social development is the achievement of maturity in the learning process to adjust to group norms, morals and traditions, merge into one unit and communicate with each other in cooperation (Yusuf 2007:122 ). This process includes changes in individual relationships with others, emotional changes, and changes in personality. But in reality, as in Korpri Vocational School, in the initial observations there were still students who did not respect 
their peers by making fun of their friends, did not want to help their friends like cleaning classes, there were still violating school rules, and students who did not get along with friends who others. Therefore social behavior on students needs to be invested by the teacher to students not merely the acquisition of the material being taught but also have faith in God and the pattern of a good relationship towards fellow human beings.

Based on the background above, it can be concluded that social behavior means a form of piety based on social Islamic morality or Islamic social behavior which intercepts one another, works good deeds, respects others, maintains brotherhood, please help and associate with other friends.

\subsection{Islamic Learning}

\section{Literature Review}

Learning is the actualization of the curriculum that requires teacher activeness in creating and growing the activities of students in accordance with the programmed plan. The teacher must master the principles of learning, choose and use learning media, the ability to assess the learning outcomes of the participants in the study, and choose and use learning strategies or approaches (Mulyasa 2011:117). According to (Uzer Usman 2010: 34) the learning process is a process that contains a series of actions of teachers and students on the basis of reciprocal relationships that take place in an educational situation to achieve certain goals. Learning is essentially a process of interaction between students and their environment, so that there is a better change in behavior. Learning is an integral (whole integrated) and intentional activity between students and teachers to achieve goals that have been formulated, namely the existence of changes in behavior including knowledge, experience, skills, and characters so on. (Kunandar 2013) said that "learning is the process of interaction between students and their environment so that behavior changes occur towards a better direction". In learning the most important task is to identify the environment in order to support the occurrence of behavior for students. Whereas (Dimyati \& Mudjiono 2013) "Learning is a process organized by teachers to teach students to learn and process knowledge, skills and attitudes."

The science of Islamic education has an important meaning and role in life. (Uhbiyati $2008: 16-17$ ) argues that the science of Islamic education has the function of verifying Islamic academic theories which summarize the aspirations or ideals of Islam that must be considered to be true. in addition, Islamic Education provides information materials about the implementation of Islamic Education. He gave the input in the form of input to this knowledge, the mechanism of the Islamic education process, from an operational point of view it can be formulated with a process that can be equated with the process of mechanisms originating from government inputs (inputs), then processed in education activities (in the form of institutional or non-institutional which is called truput). Then it ends at the output (expected result).

\subsection{Social behavior}

Social behavior means regarding public interests (helping, giving and others). (Srijanti 2007) said "social behavior is an obedience in carrying out worship in the form of Islamic social morality .According to (Mahmud 2012), social behavior is the behavior of someone who is able to do the right balance, is committed to all relations with other humans, at home or in the community (Ali, 2000: 24) said that whereas according to Guntur; Social 
behavior is all kinds of virtues that are addressed to all humans, for example working to earn a living for wife, children and family (Sibary, 2007: 133) said that social behavior is a relative nature to respond to other people in different ways. For example in doing cooperation, there are people who do it diligently, patiently and always prioritize the common interest above their personal interests. while the common interest is above his personal interests. While on the other hand, there are people who are lazy, impatient and just want to make a profit themselves.

Sosocial behavior is a form of piety based on Islamic social morality or Islamic social behavior. Based on the above description is essentially human social beings since being humanized requires a relationship with other people to fulfill their biological needs. In the development towards maturity, social interaction between humans can realize their lives individually. This is because if there is no reciprocity of social interaction, humans cannot realize their potential as whole individuals as a result of social interaction. Its potentials as individuals are initially known from their daily behavior. In social time people will show social behavior.

\subsection{Research Hypothesis}

Government Regulation No.19 of 2005 concerning National Education Standards, teachers in Indonesia are expected to have four competencies in carrying out their profession, namely pedagogical competence, personality competence, professional competence and social competence (Chatib, 2010: 28). Therefore the role of the teaching staff (teacher) in daily life is very urgent because the teacher is in direct contact with students, the teacher also knows the condition of the students well, so that good teachers will know what to do in presenting lesson material in accordance with the conditions and needs of children students at that time. The teacher is an important and main factor, because the teacher is the person who is responsible for the physical and spiritual development of students, especially in school, to achieve maturity of students so that he becomes a complete human being and knows his duties as a human (Muhibbinsyah 2010:32). Efforts to teach students can be designed not only in interacting with the teacher as the only source of learning, but interacting with all learning resources that might be used to achieve the desired learning outcomes. as AECT (Association Education Center and Technology) that learning resources can be in the form of messages, people, materials, tools, techniques and backgrounds or the environment (Abdul $2011: 12$ ) . in addition, social behavior in students needs to be instilled by the teacher so that students not only master the material taught but also have devotion to God and a good pattern of relationships with fellow humans. Several studies have proven empirically that there is a positive relationship between learning Islamic religion in shaping the character and attitudes of students (Felistas 2015) ; (Kartowagiran and Maddini 2015). While research (Niculescu and Norel 2013) states that religious education in schools is a very important factor that not only provides material about understanding and mutual respect between humans, but also becomes the foundation in shaping the personality of students. The importance of religious education for schools as explained by (Edd 2016) that schools have made religious education a necessity whose position is very important to be applied in the real life of students. Religious learning is believed to be a factor that attracts students to interest in participating in learning Islamic religion with the method presented has added value to students (Ubale, Nasir, and Abdullah 2015) said that religious education is also believed to be able to shape the student's strength factor which is an added value in facing the current of globalization (Hasan 2017) . 
Based on the theory and empirical study, the framework is described as follows:

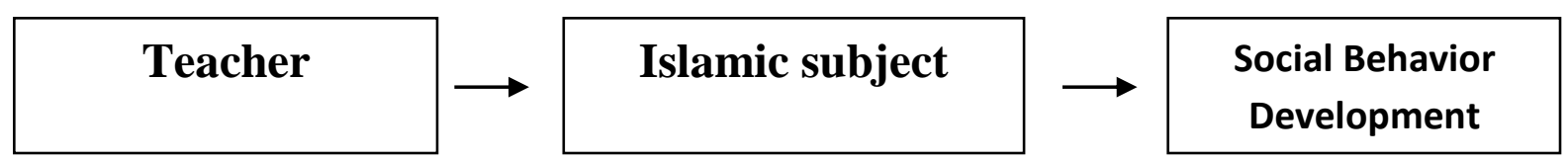

Figure 1. Thinking Framework

Based on this figure above, then the hypothesis in this study is "The significant of learning Islamic education to the development of students' social behavior".

\section{Research Method}

The method used in this study is descriptive and verification method. The researcher used the descriptive method because it would describe an actual symptom or problem that occurred in the school during the learning process, while the verification method was conducted to test the hypothesis in this study. The population in this study were all students of class XI in the Korpri Vocational School in Cigasong Village, Cigasong District, Majalengka Regency, which amounted to 553 people. Determination of the sample in this study refers to opinions (Arikunto 2002: 120) which is taking a sample of $10 \%$ of the total population of 55 students. Sources of data in this study are primary data and secondary data collection techniques by observation, documentation, interviews and questionnaires research to respondents. Data processing techniques in this study used product moment correlation techniques which were preceded by testing validity, reliability and normality. Whereas to test the hypothesis in this study using product moment correlation and to interpret the value (rxy) the researcher refers to the product moment table as follows:

Table. 1 Interpretation of Product moment correlation

\begin{tabular}{|c|c|}
\hline $\begin{array}{c}\text { The amount of "r" Product Moment } \\
(\mathrm{rxy})\end{array}$ & Interpretation of correlation \\
\hline $0.001-0.200$ & Very low correlation \\
\hline $0.200-0.400$ & Low correlation \\
\hline $0.400-0.700$ & $\begin{array}{c}\text { Sufficient or moderate } \\
\text { correlation }\end{array}$ \\
\hline $0.700-0.900$ & High correlation \\
\hline $0.900-1.00$ & Very high correlation \\
\hline & (Arikuntom 2010: 319)
\end{tabular}

\section{Research Results and Discussion}

Learning Islamic Education in class XI 1 TKR Majalengka Vocational High School is inseparable from listening and evaluation activities. Basically Islamic religious education in learning activities is to have the ability to understand the material presented. To find out the success of learning Islamic Education in class XI 1 TKR Majalengka Korpri Vocational High School conducted by researchers is to observe or observe, to find out how students' learning activities take place while the learning process is taking place. The results of observations on 
student activities to determine the response of students to learning Islamic Education, can be seen in the table below.

Table. 2 Observation Results of Islamic Education Learning

\begin{tabular}{|c|l|c|c|c|}
\hline \multirow{2}{*}{ No. Indicator } & \multicolumn{3}{|c|}{ Observation result } \\
\cline { 3 - 5 } & & Well & Enough & Less \\
\hline 1 & Students' understanding of PAI material & $69 \%$ & $22 \%$ & $9 \%$ \\
\hline 2 & Motivation to learn in PAI & $62 \%$ & $18 \%$ & $20 \%$ \\
\hline 3 & Increased knowledge of students in PAI lessons & $65 \%$ & $18 \%$ & $17 \%$ \\
\hline 4 & Student response to learning Islamic Education & $72 \%$ & $17 \%$ & $11 \%$ \\
\hline & total & $67 \%$ & $18.75 \%$ & $14.25 \%$ \\
\hline
\end{tabular}

Source: research data processed

Based on Table 2 shows that the observations for the good category reached $67 \%$, the category reached 18,755 and the category reached $14,25 \%$. The results of the study on learning Islamic Religion are concluded to be quite good, but the learning activities need to be improved, because there are still around $14.25 \%$ which state that they are still not optimal. To find out the social behavior of TKR Vocational High School students in Majalengka Vocational High School, the author conducted a study of student attitudes during the research process with indicators as listed in the table below.

Table. 3 Results of Observation of Student Social Behavior

\begin{tabular}{|c|c|c|c|c|}
\hline \multirow[t]{2}{*}{ No. } & \multirow[t]{2}{*}{ Indicator } & \multicolumn{3}{|c|}{ Observation result } \\
\hline & & Well & Enough & Less \\
\hline 1 & $\begin{array}{c}\text { Obey and obediently carry out } \\
\text { worship }\end{array}$ & $76 \%$ & $18 \%$ & $6 \%$ \\
\hline 2 & Respect for teachers & $84 \%$ & $16 \%$ & - \\
\hline 3 & Solidarity & $55 \%$ & $18 \%$ & $27 \%$ \\
\hline 4 & Comply with discipline & $80 \%$ & 165 & $4 \%$ \\
\hline & total & $73.75 \%$ & $17 \%$ & $9.25 \%$ \\
\hline
\end{tabular}

Source: research data processed

From table 3 shows that based on observations for good categories reached $73,75 \%$, enough categories reached $17 \%$, and categories less reached $9.25 \%$. The results of this study indicate that the social behavior of students in Majalengka Corps Vocational School is still not optimal in its implementation, considering that there are still high indicators that lack trust in solidarity reaching $27 \%$.

The results of testing the normality of the learning variable data of Islamic Education obtained that the chi square value $(\chi 2)$ count of 12.964 is smaller than chi squared $(\chi 2)$ table at the level of $1 \%$ of 13.227 , this means that learning Islamic Education in children is normally distributed. While the results of testing the normality of variable data on social behavior that the value of chi squared $(\chi 2)$ calculated at 8.02 is smaller than the chi square $(\chi 2)$ table at the level of $1 \%$ at 9.488 this means that social behavior in children is normally distributed, because the analysis can be continued. From the data from the test results of the two variables above, it turns out that they are normally distributed. Therefore to prove the hypothesis of the relationship between learning Islamic Education with the development of 
students' social behavior, the authors analyzed the data of the two variables using the product moment technique. The results of the study showed that the value of rxy counted at 0.711 which indicates the amount (rxy) of the table $0.700-0.900$, which means there is a high correlation.

After looking at the $\mathrm{t}$ table it turns out that for $\mathrm{n}$ (55) there is no then taken at the nearest value of $\mathrm{n} \mathrm{50.} \mathrm{So} \mathrm{the} \mathrm{value} \mathrm{of} \mathrm{n} 50$ is a significance level of $5 \%$ at 2.01 and a significance level of $1 \%$ at 2.68 . So by obtaining t-count of 7,36 greater than t-table at a significance level of $5 \%$ at 2.01 or at $1 \%$ significance level of 2.68 means based on the analysis of the data it can be concluded that $t$ count $>t$ table means Ha accepted and Ho rejected thus based on the formulation of the hypothesis if Ha accepted this means that there is an influence of learning Islamic Education on the development of students' social behavior. The results of this study have relevance to research (Edd 2016) in his research has proven the hypothesis that character education is proven to influence students' attitudes and behavior. The results of this study support the results of previous studies such as those conducted by (Sukardi 2016); (Nuriman and Fauzan 2018); (Jagodzinski 2009) that religious learning has added value in forming the basic character of students in order to have personalities that are in accordance with religious norms and rules. The results of this study also support research (Mu'min 2017) that Islamic education has a positive and significant effect on students' behavior in their religious life.

\section{Conclusion}

After the researcher describes the discussion, presentation and analysis of the data, the conclusions and suggestions are described as follows.

1. Islamic Religious Education Learning TKR SMK KORPRI Majalengka, said to be successful it is evident from the test criteria normality of the data variable $\mathrm{X}$ where prices $\chi 2$ count, amounted to 12.964 is smaller than $\chi 2$ tables at the level of $1 \%$ of 13.227, this means that the learning of Islamic Education in children normally distributed.

2. Social behavior in the TKR XI class of Majalengka Vocational High School, experienced the development of the $\mathrm{Y}$ variable normality test where the price of itung 2 count, amounting to 8.02 is smaller than $\chi 2$ tables, both at the 5\% significance level of 9.4488 and at the $1 \%$ significance level 13,227, it means that the social behavior of students is normally distributed.

3. The effect of learning Islamic Education on the development of students' social behavior is high, this is based on the obtained (rxy) count of 0.711 which shows the magnitude (rxy) of the table $0.700-0.900$ which means a high correlation.

Based on the conclusions above, the suggestions in this study are described as follows:

1. PAI teachers are encouraged to make improvements and increase the activeness and learning interest of students and teachers should provide opportunities for students to ask questions about the material that has been delivered so that students really understand the subject matter.

2. Mastery of material and media mastery techniques must also be improved, besides that the use of learning media should be varied, so students do not feel bored. 
3. PAI teachers should not only emphasize the cognitive aspects alone but more emphasis also psychometric and affective aspects. This is done so that students' religious knowledge can be reflected and contained in their daily lives and lives.

\section{References}

Abdul, latif. 2011. Pendidikan Berbasis Nilai Kemasyarakatan. Bandung: Refika Aditama. Arifin, M. 2000. Ilmu Pendidikan Islam. Jakarta: Bumi Aksara.

Arikunto, Suharsimi. 2002. Prosedur Penelitian Suatu Pendekatan Praktek. Jakarta: Rineka Cipta.

Dimyati \& Mudjiono. 2013. Belajar Dan Pembelajaran. ed. Rineka Cipta. Jakarta.

Edd, Kimberly K Ilosvay. 2016. "Religion in Schools? The Importance of Recognizing the Impact of Religious Experiences." 1(2).

Felistas, Chemutai. 2015. "The Relationship between Students' Attitude and Performance in C.R.E in Secondary School Examinations. FELISTAS CHEMUTAI Moi University." International Journal of Education and Research 3(1): 235-46.

Hasan, Karnadi. 2017. "International Journal of Active Learning Strengthening The Students 'Value of Diversity in Learning in Global Era." 2(3): 59-67.

Jagodzinski, Wolfgang. 2009. "The Impact of Religion on Values and Behavior." Kwansei Gakuin University School of Sociology Journal 107: 19-34.

Kartowagiran, Badrun, and Harsul Maddini. 2015. "Evaluation Model for Islamic Education Learning in Junior High School and Its Significance to Students' Behaviours." American Journal of Educational Research 3(8): 990-95.

Kunandar. 2013. Penilaian Autentik (Penilaian Hasil Belajar Peserta Didik Berdasarkan Kurikulum 2013). Jakarta: Raja Grafindo Persada.

Mahmud. 2012. Sosiologi Pendidikan. Bandung: Sosiologi Pendidikan.

Mu'min, U. Abdullah. 2017. “The Effect Of Islamic Education Learning ( Pai ) And Learning Results To Student's Religious Behavior Of Stisip Widyapuri Mandiri Sukabumi Student." International Journal of Scientific \& Technology Research 6(06): 84-89.

Muhammad, Sabil Farooq. 2017. "Islamic Education Positive Affects at School Going Children in Pakistan Islamic Education Positive Affects at School Going Children in Pakistan." Middle-East Journal of Scientific Research 25 25(January): 1446-50.

Muhibbinsyah. 2010. Pskologi Pendidikan. Bandung: Remaja Rosdakarya.

Mulyanto. 2007. Ilmu Lingkungan. Yogyakarta: Graha Ilmu.

Mulyasa, E. 2011. Standar Kompetensi Dan Sertifikasi Guru. Bandung: Remaja Rosdakarya.

Nakayama, Minoru, Hiroh Yamamoto, and Rowena Santiago. 2007. "The Impact of Learner Characteristics on Learning Performance in Hybrid Courses among Japanese Students." The Impact of Learner Characteristics on Learning Performance in Hybrid Courses among Japanese Students Minoru 5(3): 195-206.

Niculescu, Rodica Mariana, and Mariana Norel. 2013. "Religious Education an Important Dimension of Human's Education." Procedia - Social and Behavioral Sciences 93: 338-42.

Nuriman, Nuriman, and Fauzan Fauzan. 2018. "The Influence of Islamic Moral Values on the Students' Behavior in Aceh.” Dinamika Ilmu 17(2): 275-90.

Srijanti, et al. 2007. Etika Membangun Masyarakat Islam Modern. ed. Graha Ilmu. Yogyakarta. 
Sukardi, Ismail. 2016. "Character Education Based on Religious Values: An Islamic Perspective." Ta'dib 21(1): 41.

Supardi, dkk. 2009. Pengembangan Evaluasi Sistem Pendidikan Agama Islam. Jakarta: Diadit Media.

Ubale, Adamu Zakiyu, Naja'at Nasir, and Abdul Hakim Abdullah. 2015. "Impact of Students' Interest on Learning Islamic Education among SMKA Students in Kuala Terengganu, Malaysia." Mediterranean Journal of Social Sciences 6(6): 105-12.

Uhbiyati. 2008. Ilmu Pendidikan Islam. ed. Pustaka Setia. Bandung.

Uzer Usman, Moh. 2010. Menjadi Guru Profesional. Bandung: Remaja Rosdakarya.

Yusuf, Hadi. 2007. Teknologi Komunikasi Pendidikan. Jakarta: Rajawali. 